\title{
Streptomycin in Pregnancy: Effect on the Foetal Ear
}

\author{
N. CONWAY,* M.B., M.R.C.P. ; B. D. BIRT, $\dagger$ F.R.C.S.
}

The treatment of active tuberculosis during pregnancy is complicated by the problem of the safety of the drugs employed. In order to prevent the emergence of drug-resistant organisms it is customary during the initial stages to give streptomycin as well as isoniazid and $p$-aminosalicylic acid, and, while the mother is of course subject to the risk of ototoxic damage due to streptomycin, it is not entirely clear how far this risk extends to the foetus. Certainly streptomycin does cross the placenta: this was established in 1945 by Woltz and Wiley and independently by Heilman et al. (1945). Subsequent work (Bernhard et al., 1950 ; Riskær et al., 1952 ; Charles, 1954) confirmed that, although the effectiveness of the placental barrier varies, streptomycin and dihydrostreptomycin (Jacobsen, 1953) are present in foetal blood in up to $50 \%$ of maternal concentrations. The effect of these drugs on the foetus was studied experimentally by Riskær et al., using guinea-pigs; no disturbance of auditory or vestibular function was apparent.

Watson and Stow (1948) were the first to examine this question clinically; they found no obvious abnormality in two children born after high maternal doses of streptomycin during pregnancy. Later reports agreed, and Kreibich (1954) was able to collect from the literature 35 cases in which children at risk seemed to be unaffected. Since 1950, however, several case reports have appeared of deaf children born to mothers treated with streptomycin for tuberculosis. Leroux (1950) described the case of a child aged $2 \frac{1}{2}$ with deafness (and normal caloric responses) whose mother had received $30 \mathrm{~g}$. of streptomycin in the last month of pregnancy. Bolletti and Croatto (1958) reported the case of a girl of 5 with severe deafness and impaired vestibular function, the maternal dose of streptomycin having been $1 \mathrm{~g}$. daily for 85 days prior to delivery. Kern (1962) described the case of a 6-year-old girl with severe deafness in the left ear and total deafness in the right. A caloric test evoked very little response. In this case the mother had been treated with $20 \mathrm{~g}$. of dihydrostreptomycin in the first four months of pregnancy. Finally, in a study of the causes of deafness in 300 children, Robinson and Cambon (1964) discovered two further children with severe deafness and absent caloric responses. The first mother had been given $1 \mathrm{~g}$. of streptomycin twice weekly for eight weeks in the first trimester, and the second a similar dosage for the last four months of pregnancy.

Apart from these isolated cases there have been three papers describing the otological findings in small groups of children at risk. Rebattu et al. (1960) found two cases of high tone loss among six children they examined, and in one the caloric tests were abnormal. Lenzi and Ancona (1962) studied 10 children aged $7-10$ years and their mothers. Audiograms showed that three of the children were deaf ; all the mothers were normal. Grande and Vespa (1963) examined nine mothers and their 14 children, then aged 7-11 years. In this instance all the mothers had received dihydrostreptomycin, the dose ranging from 5 to $80 \mathrm{~g}$. Four mothers and three children had perceptive deafness; five more children had mixed deafness. Vestibular function was studied with galvanic and caloric tests, of which no details were given; all the children were stated to be normal.

These three series suggest a relatively high incidence of deafness (possibly related in the last one to the use of dihydrostreptomycin, which is more apt than streptomycin itself to damage cochlear function), and it is therefore surprising that so few children with deafness caused in this way have been reported. The present investigation was undertaken in an attempt to reassess the incidence of deafness in children at risk. Furthermore, in theory one would expect labyrinthine rather than cochlear damage to be the commoner finding after the use of streptomycin, and accordingly vestibular function was examined in detail.

\section{Material and Methods}

During 1950 to 1959 , inclusive, 336 women with tuberculosis were delivered at the Obstetric Hospital (University College Hospital). Their case records were examined and 24 were found to have received streptomycin or dihydrostreptomycin at some time during their pregnancy. Of these, 18 were traced, two had left England, one had died, and three failed to reply. The child of one mother had died of gastro-enteritis at the age of 5 months.

Each mother was seen in the out-patient department with her child. She was questioned about the child's development, activities, and medical history, and about her own pregnancy. Additional information was obtained from the case records. Examination of the child's ears, nose, and throat was followed by a routine general examination, an audiogram, and, finally, by the standard caloric tests of Fitzgerald and Hallpike (1942) carried out by one of us (B. D. B.). The mother herself had an audiogram and caloric tests after preliminary otoscopic examination. All audiograms were carried out in a soundproof room, using a Peters S.P.D.5 audiometer (British Standard). Air-conduction thresholds were measured, and, if these were abnormal, bone conduction.

\section{Results in Children}

All the children were apparently leading normal lives at home and at school and all had developed uneventfully. There were no disorders of gait and none of them experienced any difficulty in balancing while climbing or in the dark. All could ride a bicycle except two (who had not tried). Ten could swim and the rest had not been taught.

Previous Medical History.-No child had received streptomycin since birth. Five had had otitis media (Cases 1, 8, 12, 13, and 17) and five had undergone adeno-tonsillectomy (Cases 4, 5, 9, 12, and 14). All except two (Cases 2 and 16) had had measles and eight had had mumps (Cases 1, 3, 9, 10, 13, 14, 15, and 16). One child (Case 9) had sustained a depressed fracture of the skull six years previously. This had been elevated and a small extradural haematoma evacuated. Another (Case 1) was known to have symptomless congenital heart disease diagnosed on clinical grounds as a small ventricular septal defect at another hospital six years previously.

E.N.T. Examination.-Retracted tympanic membranes were noted in Cases 8 and 12. No other abnormality was'found.

General Examination.-In Case 1 the boy had a short systolic murmur maximal at the pulmonary area and conducted down

* Medical Registrar, University College Hospital, London.

† Registrar, Royal Ear Hospital, University College Hospital, London. 
the left sternal edge. There was no thrill. Both elements of the second sound were audible. The chest was asymmetrical, with prominence of the ribs in the left parasternal region; no abnormal pulsation was present. The pulse was normal and the femoral pulses were present. In Cases 2, 6, and 12 a systolic murmur was heard in the pulmonary area. It was unaccompanied by a thrill or evidence of ventricular hypertrophy. The pulmonary second sound could not be heard in Case 6. Arachnodactyly was noted in Cases 6 and 12.

Audiograms.-An abnormal audiogram is defined in this paper as one showing an air-conduction threshold below 20 decibels at any frequency. This was classified as mild deafness. If there was any frequency with a threshold below 40 decibels the term moderate deafness was applied, and if any were below 60 decibels severe deafness. Four children had unilateral hightone hearing loss of perceptive type (see Table I).

Caloric Tests. - These were considered to be abnormal if the duration of nystagmus after starting irrigation was 80 seconds or less. Six children had abnormal responses (see Table I). Those having no response at all at the standard temperatures $\left(30^{\circ}\right.$ and $44^{\circ} \mathrm{C}$.) were tested with water at $20^{\circ} \mathrm{C}$.

\section{Results in Mothers}

Fourteen mothers were treated with streptomycin and three (Cases 2, 7, and 17) with Myxtamycin (equal proportions of streptomycin and dihydrostreptomycin). Details of dosage are given in Tables I and II, and include streptomycin received both in pregnancy and at other times. No toxic effects were experienced by any mother during pregnancy, but one (Case 7) became giddy four months after delivery. One mother (Case 16) had been investigated for giddiness associated with typical migraine one year before her pregnancy. At that time she had a normal audiogram but her caloric tests showed minimal asymmetry which might be interpreted as demonstrating hypofunction of the right vestibular apparatus. No diagnosis other than migraine was made and her symptoms disappeared.

None of the mothers had any illness during pregnancy other than tuberculosis, but two had operations: a lobectomy at the fourth month (Case 9) and a thoracoplasty at the sixth month (Case 11). One was delivered by caesarean section (Case 17) and another had a forceps delivery for foetal distress (Case 9). The other deliveries were all normal. Only one child was premature (Case 15-birth weight, 4 lb. 7 oz. ; 2,015 g.). There

TABLE I.-Children with Abnormal Tests

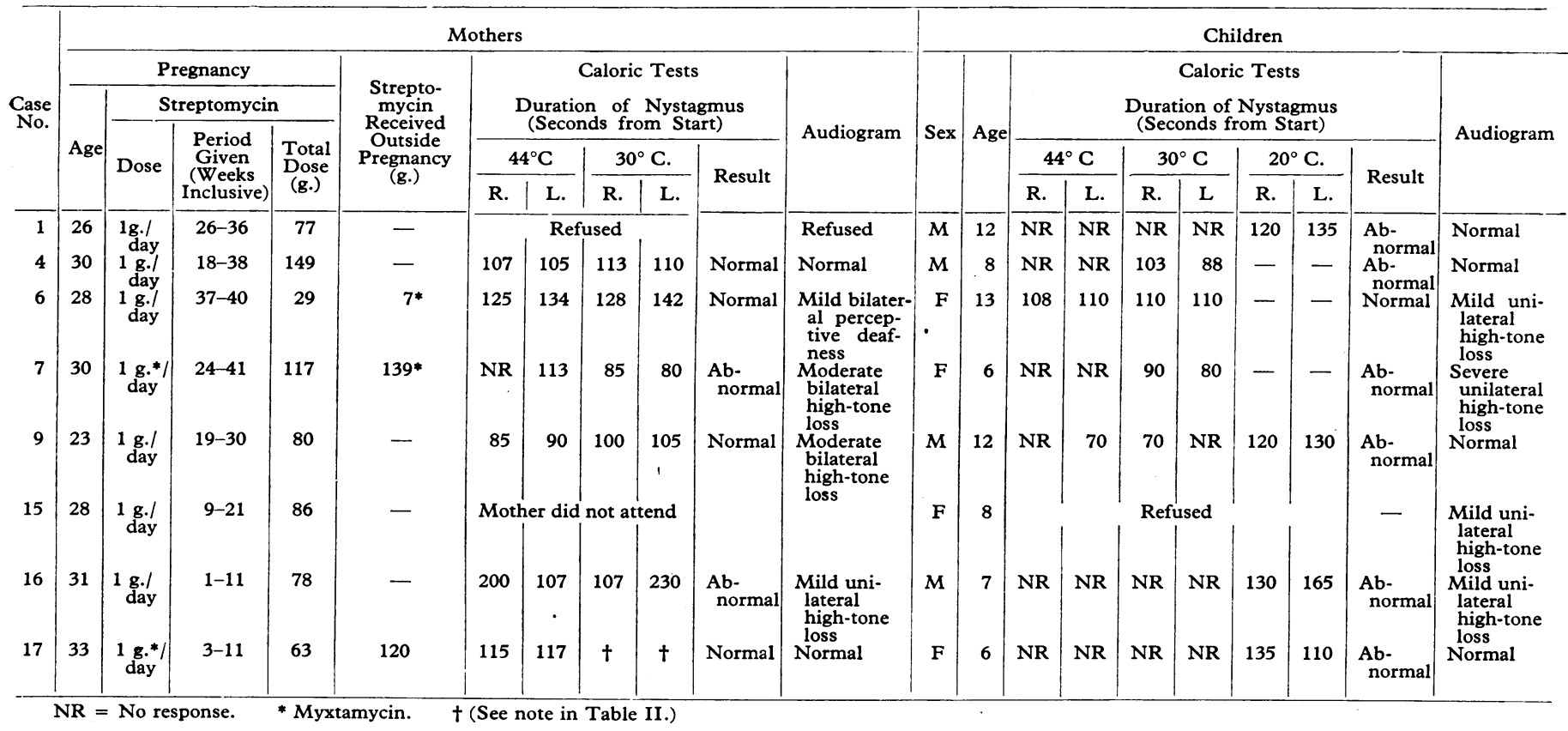

TABLE II.-Normal Children

\begin{tabular}{|c|c|c|c|c|c|c|c|c|c|c|c|c|c|c|c|c|c|c|c|}
\hline \multirow{5}{*}{$\begin{array}{l}\text { Case } \\
\text { No. }\end{array}$} & \multicolumn{11}{|c|}{ Mothers } & \multicolumn{8}{|c|}{ Children } \\
\hline & \multicolumn{4}{|c|}{ Pregnancy } & \multirow{4}{*}{$\begin{array}{c}\text { Strepto- } \\
\text { mycin } \\
\text { Received } \\
\text { Outside } \\
\text { Pregnancy } \\
\quad \text { (g.) }\end{array}$} & \multirow{2}{*}{\multicolumn{5}{|c|}{$\begin{array}{l}\text { Caloric Tests } \\
\text { Duration of Nystagmus } \\
\text { (Seconds from Start) }\end{array}$}} & \multirow{4}{*}{ Audiogram } & \multirow{4}{*}{ Sex } & \multirow{4}{*}{ Age } & \multirow{2}{*}{\multicolumn{5}{|c|}{$\begin{array}{l}\text { Caloric Tests } \\
\text { Duration of Nystagmus } \\
\text { (Seconds from Start) }\end{array}$}} & \multirow{4}{*}{ Audiogram } \\
\hline & \multirow{3}{*}{ Age } & \multicolumn{3}{|c|}{ Streptomycin } & & & & & & & & & & & & & & & \\
\hline & & & Period & & & \multicolumn{2}{|c|}{$44^{\circ} \mathrm{C}$} & \multicolumn{2}{|c|}{$30^{\circ} \mathrm{C}$} & \multirow[b]{2}{*}{ Result } & & & & \multicolumn{2}{|c|}{$44^{\circ} \mathrm{C}$} & \multicolumn{2}{|c|}{$30^{\circ} \mathrm{C}$} & \multirow[b]{2}{*}{ Result } & \\
\hline & & Dose & $\begin{array}{c}\text { (Weeks } \\
\text { Inclusive) }\end{array}$ & $\begin{array}{c}\text { Dose } \\
\text { (g.) }\end{array}$ & & R. & L. & R. & L. & & & & & R. & L. & R. & L. & & \\
\hline $\begin{array}{l}2 \\
3\end{array}$ & $\begin{array}{l}27 \\
34\end{array}$ & $\begin{array}{l}1 \mathrm{~g} . * / \text { day } \\
1 \text { g. } 3 \text { days } \\
\text { a week }\end{array}$ & $\begin{array}{l}23-33 \\
25-39\end{array}$ & $\begin{array}{l}77 \\
41\end{array}$ & 91 & \multicolumn{3}{|c|}{$105|108|-$} & - & Normal & $\begin{array}{l}\text { Refused } \\
\text { Normal }\end{array}$ & $\begin{array}{l}\mathrm{F} \\
\mathrm{F}\end{array}$ & $\begin{array}{r}6 \\
10\end{array}$ & $\begin{array}{l}98 \\
90\end{array}$ & $\begin{array}{l}80 \\
90\end{array}$ & $\begin{array}{l}90 \\
+\end{array}$ & $\stackrel{108}{t}$ & $\begin{array}{l}\text { Normal } \\
\text { " }\end{array}$ & $\begin{array}{c}\text { Normal } \\
\text { " }\end{array}$ \\
\hline 5 & 35 & $1 \mathrm{~g} . / \mathrm{day}$ & $16-26$ & 68 & - & 120 & 150 & 125 & 135 & " & $\begin{array}{l}\text { Mild } \\
\text { bilateral } \\
\text { perceptive }\end{array}$ & $M$ & 8 & 107 & 116 & 116 & 120 & " & ” \\
\hline 8 & 26 & $\begin{array}{c}1 \text { g. twice } \\
\text { weekly } \\
1 \text { g. } 6 \text { days } \\
\text { a week }\end{array}$ & $\begin{array}{l}1-8 \\
9-39\end{array}$ & 202 & 312 & 130 & 115 & 100 & 125 & ” & $\begin{array}{l}\text { deatness } \\
\text { Normal }\end{array}$ & $\mathrm{F}$ & 9 & 110 & 110 & 118 & 115 & " & " \\
\hline $\begin{array}{l}10 \\
11 \\
12 \\
13\end{array}$ & $\begin{array}{l}21 \\
22 \\
29 \\
25\end{array}$ & $\begin{array}{l}1 \text { g./day } \\
1 \text { g./day } \\
1 \text { g./day } \\
1 \text { g. twice }\end{array}$ & $\begin{array}{r}4-13 \\
16-34 \\
30-40 \\
1-41\end{array}$ & $\begin{array}{r}65 \\
131 \\
79 \\
82\end{array}$ & $\frac{\overline{126}}{224}$ & $\begin{array}{r}120 \\
109 \\
85\end{array}$ & $\begin{array}{c}\text { Ref } \\
135 \\
118 \\
95\end{array}$ & $\begin{array}{r}\text { used } \\
129 \\
107 \\
110\end{array}$ & $\begin{array}{l}124 \\
120 \\
112\end{array}$ & $\begin{array}{l}\text { Normal } \\
\text { \#" }\end{array}$ & "”, & \begin{tabular}{c|}
$M$ \\
$M$ \\
$F$ \\
$M$
\end{tabular} & $\begin{array}{r}7 \\
11 \\
12 \\
9\end{array}$ & $\begin{array}{r}123 \\
98 \\
103 \\
90\end{array}$ & $\begin{array}{l}105 \\
117 \\
107 \\
105\end{array}$ & $\begin{array}{c}\dagger \\
128 \\
105 \\
118\end{array}$ & $\begin{array}{c}t \\
135 \\
106 \\
112\end{array}$ & "” & "” \\
\hline 14 & 25 & $\begin{array}{l}\text { 1 g. twice } \\
\text { weekly }\end{array}$ & $1-40$ & 80 & 279 & 125 & 150 & 145 & 175 & , & $\begin{array}{l}\text { Mild uni- } \\
\text { lateral } \\
\text { high-tone } \\
\text { loss }\end{array}$ & $\mathrm{F}$ & 9 & 101 & 107 & 127 & 115 & " & " \\
\hline
\end{tabular}


was no rhesus incompatibility. No cases of pyelitis occurred in pregnancy, but one mother had mild toxaemia just before term (Case 2).

Other drugs given during pregnancy were isoniazid (Case 4), p-aminosalicylic acid (Cases 1, 9, 12, 13, and 14), or both these drugs (Cases 2, 3, 5, 7, 8, 10, 11, 15, 16, and 17). All received oral iron, four had barbiturates (Cases 4, 7, 14, and 17), two had antihistamines (Cases 2 and 8), and one had carbromal (Case 6).

Audiograms.-These were carried out on 14 mothers. Six were abnormal, four with high-tone loss and two with mild perceptive deafness across the speech frequencies (see Tables I and II).

Caloric Tests.-Thirteen mothers had these performed. Two were abnormal (see Table I).

\section{Discussion}

Our results have not revealed hearing loss in the speech frequencies in any of our children. Four had thresholds below 20 decibels at the highest frequency tested (8,000 c.p.s.), in each case in one ear only, and it is worth noting that Robinson and Cambon (1964) speculated that cases of mild and unilateral hearing loss might be found in children at risk if careful audiological surveys were made.

Six of our children had abnormal caloric tests (without, however, complete loss of labyrinthine function), but only two of these had abnormal audiograms. It was shown by Bignall et al. (1951), testing adults made giddy by streptomycin, that the earliest evidence of labyrinthine damage was loss of caloric response to hot water. Two of the children showed precisely this change. The others were unresponsive to both hot and cold water $\left(44^{\circ}\right.$ and $30^{\circ}$ C.) but reacted at $20^{\circ}$ C. (a much stronger stimulus). All the children reported in the literature with absent caloric responses have been deaf, but our findings confirm that labyrinthine damage without deafness does occur.

It is important to emphasize that none of our six affected children experienced any disability in their day-to-day activities. Of course all had some residual vestibular function and presumably had compensated for their loss, but it seems likely that even children with complete labyrinthine destruction caused in this way before birth would experience little, if any, inconvenience (except, conceivably, in special circumstances such as movement in total darkness or swimming under water (Chusid and de Gutiérrez-Mahoney, 1946)). Nevertheless, these six children might prove peculiarly vulnerable to toxic labyrinthine injury if in the future they were to be given streptomycin, and probably its use should be avoided. Indeed, it would be prudent to carry out tests of eighth-nerve function in any child who has been exposed to antenatal streptomycin before allowing him to have the drug again.

It is difficult to explain why some children developed eighth-nerve damage and others escaped. Examination of the details of maternal streptomycin dosage suggests no obvious relation either to the period of pregnancy during which the drug was given or to the total amount received, but the administration of streptomycin every day cannot be exonerated, since the children of the four mothers who received intermittent dosage were all in the normal group. In four families both mother and child had evidence of eighth-nerve damage, although the results in one mother must be treated with reserve in view of her past history. Unfortunately, the mothers of two of the remaining four affected children were not available for testing. Only one mother had symptoms of streptomycin toxicity, and she and her child both had abnormal audiograms (see Fig.) and caloric tests. Her case is of particular interest in that she continued treatment with streptomycin for four months after delivery before developing vertigo. Such results suggest a factor influencing both mother and child in these families-for example, impairment of maternal renal function or familial sensitivity (Pražić et al., 1964)-but the placental transmission of streptomycin is apparently variable, and it may be that this, or biological idiosyncrasy, could account for the appearance of eighth-nerve lesions in particular children. It is also important to recognize the danger of attributing abnormal audiograms (especially in the mothers) specifically to streptomycin damage (Gillam, Archard, and Dunn-to be published).

The first child seen had a known congenital heart lesion. Three others were found to have pulmonary systolic murmurs but were symptom-free, and further investigation was thought unjustifiable. The significance of these findings therefore remains uncertain.

Clearly, there are risks associated with the use of streptomycin in pregnancy. This investigation suggests that minor degrees of eighth-nerve damage may be common: in our children, at least, the immediate effects were unimportant. Examination of large numbers of children is needed to put the risks into perspective.

\section{Summary}

Seventeen children aged 6-13 years whose mothers received streptomycin during pregnancy were examined. Eight were found to have minor abnormalities of eighth-nerve function, caloric tests being abnormal in six and audiograms in four: no deafness was found in the speech frequencies. Although no child had any apparent disability, it is suggested that such children may be peculiarly liable to toxic labyrinthine injury and should have tests of eighth-nerve function before being given streptomycin in future. Possible factors influencing the appearance of ototoxic damage in any particular child are discussed. The literature is reviewed, and it is concluded that further work is required to evaluate the risks to the foetus of streptomycin given in pregnancy.

We are grateful to Dr. Howard Nicholson for suggesting this investigation and for his help and encouragement. We wish to
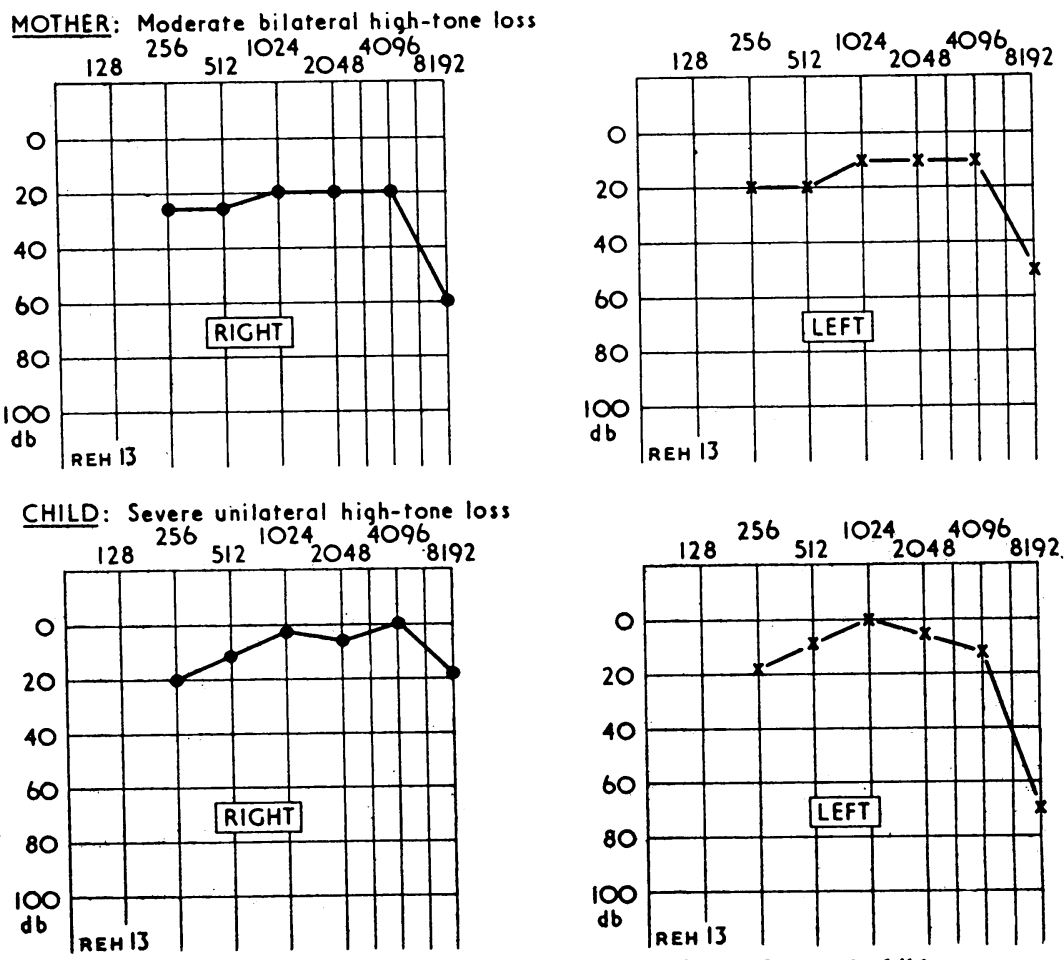

Case 7. Audiograms illustrating hearing loss in mother and child. 
thank Mr. Myles Formby for kindly reading the manuscript and for his advice. We are indebted to Miss $M$. Slemeck and Miss $M$. Ashley for performing all the audiograms.

\section{REFERENCES}

Bernhard, E., Kreis, B., Lotte, M., and Poley, M. P. Y. (1950). Bull. Acad. nat. Méd. (Paris), 134, 41.

Bignall, J. R., Crofton, J. W., and Thomas, J. A. B. (1951). Brit. med. f., 1, 554 .

Bolletti, M., and Croatto, L. (1958). Acta paediat. lat. (Reggio Emilia), 11, 1 .

Charles, D. (1954). f. Obstet. Gynaec. Brit. Emp., 61, 750.

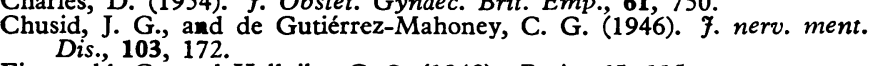

Fitzgerald, G., and Hallpike, C. S. (1942). Brain, 65, 115.
Grande, F., and Vespa, F. (1963). Arch. Tisiol., 18, 772.

Heilman, D. H., Heilman, F. R. Hinshaw, H. C. Nichols, D. R., and Herrell, W. E. (1945). Amer. F. med. Sci., 210, 576.

Jacobsen, B. E. (1953). Ugesk. Lag., 115, 1181

Kern, G. (1962). Schweiz. med. W schr., 92, 77.

Kreibich, H. (1954). Dtsch. Gesundh.-Wes., 9, 177.

Lenzi, E., and Ancona, F. (1962). Riv. ital. Ginec., 46, 115

Leroux, L. (1950). Ann. Oto-laryng. (Paris), 67, 194.

Pražić, M., Salaj, B., and Subotić, R. (1964). ł. Laryng., 78, 1037.

Rebattu, J. P., Lesne, G., and Megard, M. (1960). F. franç. Oto-rhinolaryng., 9, 411.

Riskær, N., Christensen, E., and Hertz, H. (1952). Acta tuberc. scand., 27, 211 .

Robinson, G. C., and Cambon, K. G. (1964). New Engl. F. Med., 271, 949.

Watson, E. H., and Stow, R. M. (1948). F. Amer. med. Ass., 137, 1599.

Woltz, J. H., and Wiley, M. M. (1945). Proc. Soc. exp. Biol. 'N.Y.), 60, 106

\title{
Anti-prostate Antibodies in Arthritis
}

\author{
A. GRIMBLE,* M.D., M.R.C.P. ; M. H. LESSOF, $†$ M.D., M.R.C.P.
}

Brit. med. F., 1965, 2, 263-264

Little evidence has been offered to explain the association between the lower genito-urinary inflammation of Reiter's syndrome and the polyarthritis and conjunctivitis which follow. The presence of an infective agent has seemed likely but remains unproved. The syndrome follows a urethritis, though this may go unrecognized at the time. Subacute prostatitis is thought to be an important feature, as it may also be in ankylosing spondylitis (Mason et al., 1958). It is possible, therefore, that the joint manifestations of this disease may depend on a hypersensitive reaction, and that an underlying prostatitis may play a part. In a number of cases a circulating antibody to a prostatic antigen has been demonstrated (Grimble, 1964).

This paper is concerned with a review of 400 cases in which tests were made for antibody to a prostatic antigen. The test used was the haemagglutination test previously described (Grimble, 1964). The majority of male patients in this series had been diagnosed as having Reiter's syndrome, ankylosing spondylitis, rheumatoid arthritis, prostatitis, conjunctivitis, or uveitis. A miscellaneous group of 116 subjects had other disorders, usually affecting the joints, genito-urinary tract, or eyes. The object of this study was to assess the clinical usefulness of the test and to consider whether the results had a significant bearing on the aetiology of these diseases.

\section{Patients Studied and Methods}

For a presumptive clinical diagnosis of Reiter's syndrome (Brodie, 1818) in the acute stage two criteria were requiredarthritis together with urethritis. The presence of conjunctivitis made the diagnosis a firm one. Joint pains and prostatitis in the presence of clinical or radiological evidence of plantar fasciitis or periostitis, or in the presence of a history or clinical evidence of conjunctivitis, uveitis, or keratodermia blennorrhagica, were likewise thought to be sufficient evidence for a presumptive diagnosis of Reiter's syndrome. In a number of cases lacking these full criteria a diagnosis of possible Reiter's syndrome was made.

The diagnosis in other groups of cases rested on the generally accepted clinical features, aided by $x$-ray evidence of sacro-iliac involvement in the case of ankylosing spondylitis, and by a positive latex or Rose-Waaler test in 35 of the males and 42 of the females with rheumatoid arthritis. The miscellaneous group included undiagnosed polyarthritis (48 cases), degenerative arthritis (22 cases), psoriatic arthropathy (7 cases), and 39 other

\footnotetext{
* Physician in charge of Department of Venereology, Guy's Hospital, London.

† Senior Clinical Tutor, Guy's Hospital, London.
}

cases presenting with limb pain, genito-urinary symptoms, or eye disease.

For the haemagglutination test a $4 \%$ suspension of tanned sheep red cells was used. These cells were sensitized by exposure for 30 minutes to a mixture of proteins derived from human prostate by phenolic extraction. The prostatic material was obtained at necropsy from young subjects who had no obvious prostatic disease. Two to $2.5 \mathrm{mg}$. of the freeze-dried antigen was suspended in $5 \mathrm{ml}$. of isotonic saline for the sensitizing procedure, the concentration being selected to give uniform results with known positive sera from patients and serum from immunized rabbits. Each patient's serum was tested at serial dilutions of between 1 in 20 and 1 in 320 ; in the light of previous experience agglutination at 1 in 20 was regarded as a positive result. Despite the known sensitivity of haemagglutination procedures, titres above $1: 160$ were not very common. Titres greater than 1:1,000 have, however, been noted.

A minor modification of the test has involved a more prolonged absorption of test serum with an equal volume of packed sheep red cells for 20 minutes. This was found to diminish the tendency of certain sera to cause non-specific agglutination, affecting not only sensitized but also unsensitized sheep red cells. Each serum found to be positive in the routine test was then rechecked to ensure the specificity of the agglutination. This was done by adding $0.25 \mathrm{mg}$. of prostatic antigen to $0.1 \mathrm{ml}$. of serum, and after this specific absorption with antigen various dilutions of the serum were retested. A specific positive reaction was one in which haemagglutination occurred in the original test but did not occur after absorption of the serum with prostatic antigen. As only one concentration of antigen was used this technique may have failed to absorb out true antibody in certain cases. Since completing this study we have had evidence of this in two cases of ankylosing spondylitis and one of Reiter's syndrome which now give positive results of proved specificity but had previously been reported as giving non-specific agglutination.

\section{Results}

Reiter's syndrome was diagnosed in 28 cases, 23 of which gave positive reactions and 15 had specific positive tests for antibody to prostatic antigen (see Table I). Four out of 20 possible cases of Reiter's syndrome were also specifically positive, and so also were 18 out of 46 cases of ankylosing spondylitis. This was evidently not an exclusive test for Reiter's syndrome and ankylosing spondylitis, since it was found 